\title{
DETERMINAN LOYALITAS NASABAH (STUDI PADA BANK SYARIAH DI KOTA MADIUN)
}

\author{
Nik Amah \\ IKIP PGRI Madiun \\ sigmaku87@gmail.com
}

\author{
Septi Hendriana \\ IKIP PGRI Madiun
}

\begin{abstract}
This study aims to examine the determinants of customer loyalty to the Islamic bank in the City of Madison. Determinant of customer loyalty were researched including service performance and customer satisfaction. If the performance of services delivered according to expectations the bank customer, then the customer will be satisfied. Satisfaction is a good reason for customers to repeat the use of bank services related. Customer satisfaction at a later stage will create customer loyalty. The study uses primary data and data collection instrument was a questionnaire. Mechanical calculation using the formula Slovin samples in order to obtain a sample of 138 customers. Research use accidental sampling technique to assign the sample. Multiple regression analysis was used to analyze the data. The results showed that the effect of service performance on customer loyalty Bank Muamalat Tbk. Branch Madiun. Satisfaction effects on customer loyalty Bank Muamalat Tbk. Branch Madiun. Service performance and satisfaction simultaneously affect the customer loyalty Bank Muamalat Tbk. Branch Madiun.
\end{abstract}

\begin{abstract}
ABSTRAK
Penelitian ini bertujuan untuk menguji determinan loyalitas nasabah pada bank Syariah di Kota Madiun. Determinan loyalitas nasabah yang diteliti meliputi kinerja pelayanan dan kepuasan nasabah. Jika kinerja pelayanan yang disampaikan bank sesuai harapan nasabah, maka nasabah akan merasa puas. Kepuasan menjadi dasar yang baik bagi nasabah untuk mengulang kembali penggunaan jasa bank terkait. Kepuasan nasabah pada tahap berikutnya akan menciptakan loyalitas pelanggan. Penelitian menggunakan data primer dan instrumen pengambilan data berupa kuesioner. Teknik penghitungan sampel menggunakan rumus Slovin sehingga diperoleh sampel sejumlah 138 orang nasabah. Penelitian memanfaatkan teknik accidental sampling untuk menetapkan sampel. Analisis regresi berganda digunakan untuk menganalisis data. Hasil penelitian menunjukkan bahwa kinerja pelayanan berpengaruh terhadap loyalitas nasabah Bank Muamalat, Tbk. Cabang Madiun. Kepuasan berpengaruh terhadap loyalitas nasabah Bank Muamalat, Tbk. Cabang Madiun. Kinerja pelayanan dan kepuasan secara simultan berpengaruh terhadap loyalitas nasabah Bank Muamalat, Tbk. Cabang Madiun.
\end{abstract}

\section{PENDAHULUAN}

Keinginan umat Islam untuk menghindarkan kegiatan muamalahnya dari sistem riba menjadikan perbankan syariah sebagai alternatif penyedia jasa perbankan yang diminati oleh umat. Perkembangan bank syariah di Indonesia didukung adanya fakta bahwa selama ini bank syariah mampu membidik pasar syariah loyalis, yaitu konsumen yang meyakini bahwa bunga bank itu haram. Selain itu, bank syariah telah membuktikan ketangguhannya saat krisis ekonomi melanda Indonesia tahun 1997-1998. Saat terjadi krisis ekonomi bank syariah mampu bertahan dibanding bank-bank konvensional yang justru collab. Dari pengalaman 
tersebut nasabah pengguna jasa perbankan mulai beralih minat untuk menggunakan jasa perbankan syariah.

Perbankan syariah di Indonesia mulai memperlihatkan eksistensinya dan tentu saja berkompetisi dengan perbankan konvensional. Persaingan yang terjadi antara bank konvensional dan bank syariah adalah persaingan untuk memperoleh dan mempertahankan nasabah. Kedua jenis bank tersebut berlomba-lomba untuk memberikan pelayanan yang terbaik, menciptakan produk jasa unggulan dengan fitur yang memberikan kemudahan kepada nasabah. Masing-masing bank senantiasa mencari cara yang menguntungkan untuk mendiferensiasikan diri dengan pesaing agar dapat memenangkan persaingan. Menurut Parasuraman, Zeithaml, dan Berry dalam Harini (2015: 44) salah satu strategi yang dapat menunjang keberhasilan bisnis sektor perbankan adalah berusaha menawarkan kualitas jasa dan kualitas pelayanan yang ditunjukkan dengan tingginya kinerja pelayanan.

Usaha terbaik dilakukan demi tujuan kepuasan nasabah yang pada akhirnya akan menciptakan loyalitas nasabah terhadap bank terkait. Nasabah yang merasa puas merupakan suatu modal bagi kelangsungan bisnis dari suatu bank. Ada beberapa faktor yang dapat mempengaruhi kepuasan nasabah bank. Salah satunya adalah service performance / kinerja pelayanan. Kinerja pelayanan menjadi faktor yang dapat diciptakan dan bahkan dikendalikan oleh bank. Manajemen bank dapat meningkatkan kinerja pelayanan yang diberikan kepada nasabah melalui berbagai hal. Sebagai contoh penyediaan fasilitas ruang tunggu yang nyaman, karyawan yang melayani nasabah dengan tanggap dan cepat sesuai kebutuhan nasabah. Pihak bank perlu memahami benar apa yang diinginkan nasabah (Suryani, 2008: 141). Jika kinerja pelayanan yang disampaikan bank sesuai harapan nasabah, maka nasabah akan merasa puas.

Terciptanya kepuasan nasabah merupakan keuntungan bagi bank. Kepuasan menjadi dasar yang baik bagi nasabah untuk mengulang kembali penggunaan jasa bank terkait. Kepuasan nasabah pada tahap berikutnya akan menciptakan loyalitas pelanggan. Nasabah yang puas dan bahkan loyal pada suatu bank biasanya akan memberikan rekomendasi kepada orang lain untuk menggunakan jasa pelayanan bank yang sama dengan dirinya. Hal ini menguntungkan bagi bank karena secara tidak langsung bank telah merekrut calon nasabah melalui nasabah loyalnya. Kepuasan nasabah karena pelayanan pihak bank, menjadi salah satu pendorong nasabah untuk menjalin ikatan yang kuat dengan bank dalam suatu bentuk loyalitas.

Penelitian dilaksanakan pada nasabah Bank Muamalat Indonesia Tbk. Cabang Madiun. Alasan peneliti memilih bank muamalat karena bank muamalat adalah bank dengan prinsip operasional syariah pertama di Indonesia. Lebih khusus peneliti memilih Bank Muamalat Indonesia Tbk. Cabang Madiun karena meningkatnya kebutuhan jasa layanan perbankan yang berbasis syariah masyarakat di Kota Madiun dan sekitarnya. Peneliti ingin membuktikan lebih lanjut tentang kepuasan dan loyalitas nasabah bank muamalat yang merupakan bank berbasis syariah pertama di Indonesia. Peneliti ingin mengetahui faktor apakah yang dapat mempengaruhi loyalitas nasabah dengan meninjau kondisi fisik Bank Muamalat Indonesia Tbk. Cabang Madiun. Dalam penelitian ini kondisi fisik merupakan salah satu indikator dalam kinerja pelayanan. Sesuai dengan pengamatan peneliti terhadap kondisi fisik Bank Muamalat Indonesia, Tbk. cabang Madiun, diketahui bahwa ruang tunggu nasabah sudah cukup representatif dan kebersihannya terjaga. Kekurangannya adalah ruang 
parkir bank kurang luas. Pelayanan teller dan customer service bank sudah baik (sopan, ramah, dan cekatan), didukung dengan sistem nomor antrian pelayanan secara digital. Berdasarkan uraian permasalahan serta fenomena yang ada maka peneliti tertarik untuk meneliti tentang "Kepuasan Sebagai Pemoderasi Pengaruh Kinerja Pelayanan terhadap Loyalitas Nasabah".

Penelitian ini bertujuan untuk menguji pengaruh kinerja pelayanan dan kepuasan terhadap loyalitas nasabah Bank Muamalat Indonesia, Tbk. Cabang Madiun. Oleh karena itu rumusan permasalahan yang diajukan pada penelitian ini:

1. Apakah kinerja pelayanan berpengaruh terhadap loyalitas nasabah Bank Muamalat Indonesia, Tbk. Cabang Madiun?

2. Apakah kepuasan berpengaruh terhadap loyalitas nasabah Bank Muamalat Indonesia, Tbk. Cabang Madiun?

3. Apakah kinerja pelayanan dan kepuasan secara simultan berpengaruh terhadap loyalitas nasabah Bank Muamalat Indonesia, Tbk. Cabang Madiun?

Berdasarkan rumusan permasalahan yang diajukan maka hipotesis pada penelitian ini adalah:

1. Kinerja pelayanan berpengaruh terhadap loyalitas nasabah Bank Muamalat Indonesia, Tbk. Cabang Madiun.

2. Kepuasan berpengaruh terhadap loyalitas nasabah Bank Muamalat Indonesia, Tbk. Cabang Madiun.

3. Kinerja pelayanan dan kepuasan secara simultan berpengaruh terhadap loyalitas nasabah Bank Muamalat Indonesia, Tbk. Cabang Madiun.

\section{METODE}

Penelitian dilaksanakan di Bank Muamalat, Tbk. Cabang Madiun, yang beralamat di Jalan Kolonel Marhadi, No. 63 Madiun. Jenis penelitian ini adalah penelitian kuantitatif yang dikembangkan dengan desain penelitian regresi moderasi. Penelitian dilakukan untuk mengetahui pengaruh kinerja pelayanan terhadap loyalitas nasabah dan peran kepuasan sebagai pemoderasi dalam menjelaskan pengaruh kinerja pelayanan terhadap loyalitas nasabah Bank Muamalat, Tbk. Cabang Madiun. Desain penelitian dapat digambarkan sebagai berikut:

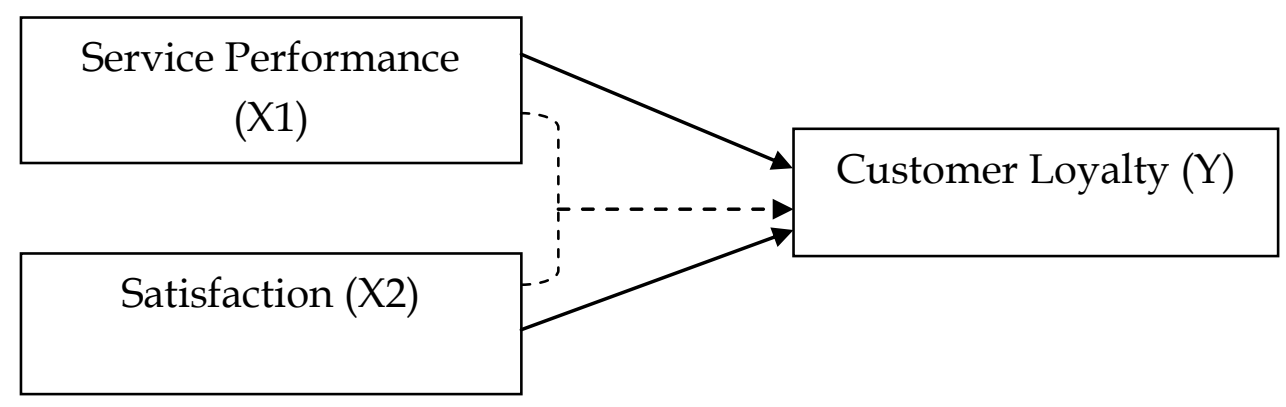

Sumber: Sugiyono (2010: 62)

Keterangan :

\section{Gambar 1. Desain Penelitian}

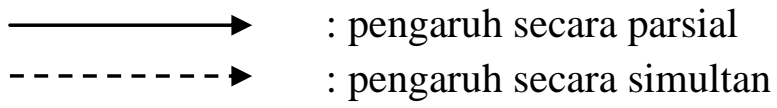


Berdasarkan desain penelitian di atas, maka variabel-variabel penelitian ini yaitu:

1. Variabel terikat: adalah variabel yang dipengaruhi oleh variabel lainnya (Arikunto, 2010: 162). Variabel terikat (Y) dalam penelitian ini adalah loyalitas nasabah. Indikator loyalitas nasabah menurut Griffin (2005) meliputi pembelian (pemanfaatan jasa) ulang secara teratur, mereferensikan produk/jasa kepada orang lain, dan menunjukkan kekebalan terhadap tarikan dari pesaing.

2. Variabel bebas: adalah variabel yang mempengaruhi variabel lainnya (Arikunto, 2010: 162). Variabel bebas (X) dalam penelitian ini adalah kinerja pelayanan dan kepuasan nasabah. Indikator kinerja pelayanan yaitu kecepatan pelayanan, kemudahan akses, kelengkapan fasilitas, sarana prasarana bank, keramahan petugas saat berkomunikasi dengan nasabah, kesanggupan petugas membantu nasabah (Cronin dan Taylor, 1994). Sedangkan, indikator kepuasan nasabah terdiri atas kepuasan keseluruhan, kepuasan jasa yang dihasilkan, perbandingan antara harapan dan kenyataan (Tjiptono dan Chandra, 2012).

Populasi penelitian adalah seluruh nasabah Bank Muamalat, Tbk. Cabang Madiun yang aktif sebagai nasabah dan melakukan transaksi perbankan selama bulan Januari Desember 2016. Teknik penghitungan sampel menggunakan rumus Slovin sehingga diperoleh sampel sejumlah 138 orang nasabah. Penelitian memanfaatkan teknik accidental sampling yaitu penetapan sampel dengan memilih sampel berdasarkan kemudahan atau secara kebetulan (Sugiyono, 2010: 124). Berdasarkan sumbernya maka data penelitian adalah data primer yang dikumpulkan dengan memanfaatkan instrumen berupa kuesioner.

Sebelum disebarkan kepada responden, kuesioner harus melalui uji instrument terlebih dahulu. Uji instrumen meliputi uji validitas dan reliabilitas. Uji validitas digunakan untuk mengukur sah atau valid tidaknya suatu kuesioner (Ghozali, 2016: 52). Pengambilan keputusan valid tidaknya item pernyataan kuesioner dapat dilihat dari nilai rhitung atau signifikansinya. Jika $\mathrm{r}$ hitung (untuk $\mathrm{r}$ tiap butir dapat dilihat pada kolom Corrected ItemTotal Correlation) lebih besar dari $r_{\text {tabel }}$ dan nilai $r$ positif, maka butir atau pertanyaan/pernyataan atau indikator tersebut dikatakan valid. Taraf signifikansi $(\alpha)$ yang digunakan adalah 0,05 atau $5 \%$.

Uji reliabilitas adalah pegujian untuk membuktikan bahwa instrumen cukup dapat dipercaya untuk digunakan sebagai alat pengumpul data karena instrumen tersebut sudah baik (Arikunto, 2010: 221). Pengambilan keputusan bahwa item pernyataan kuesioner reliabel adalah dengan melihat koefisien Cronbach Alpha. suatu konstruk atau variabel dikatakan reliabel jika memberikan nilai Cronbach Alpha > 0,70 (Ghozali, 2016: 48).

Teknik analisis data penelitian menggunakan analisis regresi berganda untuk menguji hipotesis. Namun sebelum melakukan pengujian hipotesis, terlebih dahulu dilakukan uji asumsi klasik yang terdiri dari uji normalitas data, uji multikolinearitas, uji heteroskedastisitas, dan uji autokorelasi.

\section{HASIL DAN PEMBAHASAN}

Uji validitas digunakan untuk mengukur sah atau tidaknya suatu kuesioner. Untuk mengetahui validitas item pertanyaan kuesioner dilakukan dengan membandingkan nilai rhitung dengan rtabel, jika $r$ hitung lebih besar dari $r$ tabel maka dapat dikatakan valid. Hasil uji validitas tersaji sebagai berikut: 
Tabel 1. Uji Validitas Variabel Kinerja Pelayanan

\begin{tabular}{|c|c|c|c|}
\hline Pernyataan & $\mathbf{r}_{\text {hitung }}$ & $\mathbf{r}_{\text {tabel }}(\mathbf{d f :} \mathbf{1 3 2})=\mathbf{0 , 1 6 9 7}$ & Keterangan \\
\hline Pernyataan 1 & 0,592 & $\mathrm{r}_{\text {hitung }}>\mathrm{r}_{\text {tabel }}$ & Valid \\
\hline Pernyataan 2 & 0,702 & $\mathrm{r}_{\text {hitung }}>\mathrm{r}_{\text {tabel }}$ & Valid \\
\hline Pernyataan 3 & 0,688 & $\mathrm{r}_{\text {hitung }}>\mathrm{r}_{\text {tabel }}$ & Valid \\
\hline Pernyataan 4 & 0,588 & $\mathrm{r}_{\text {hitung }}>\mathrm{r}_{\text {tabel }}$ & Valid \\
\hline Pernyataan 5 & 0,706 & $\mathrm{r}_{\text {hitung }}>\mathrm{r}_{\text {tabel }}$ & Valid \\
\hline Pernyataan 6 & 0,655 & $\mathrm{r}_{\text {hitung }}>\mathrm{r}_{\text {tabel }}$ & Valid \\
\hline
\end{tabular}

Sumber: Output SPSS

Hasil uji validitas dengan menggunakan korelasi Pearson di atas memperlihatkan nilai $r_{\text {hitung }}$ lebih besar dari nilai $r_{\text {tabel }}(0,1697)$. hal ini berarti bahwa semua pernyataan untuk mengukur variabel service performance adalah valid.

Tabel 2. Uji Validitas Variabel Kepuasan

\begin{tabular}{|c|c|c|c|}
\hline Pernyataan & $\mathbf{r}_{\text {hitung }}$ & $\mathbf{r}_{\text {tabel }}(\mathbf{d f :} \mathbf{1 2 8})=\mathbf{0 , 1 6 9 7}$ & Keterangan \\
\hline Pernyataan 1 & 0,726 & $\mathrm{r}_{\text {hitung }}>\mathrm{r}_{\text {tabel }}$ & Valid \\
\hline Pernyataan 2 & 0,672 & $\mathrm{r}_{\text {hitung }}>\mathrm{r}_{\text {tabel }}$ & Valid \\
\hline Pernyataan 3 & 0,615 & $\mathrm{r}_{\text {hitung }}>\mathrm{r}_{\text {tabel }}$ & Valid \\
\hline Pernyataan 4 & 0,536 & $\mathrm{r}_{\text {hitung }}>\mathrm{r}_{\text {tabel }}$ & Valid \\
\hline Pernyataan 5 & 0,651 & $\mathrm{r}_{\text {hitung }}>\mathrm{r}_{\text {tabel }}$ & Valid \\
\hline Pernyataan 6 & 0,659 & $\mathrm{r}_{\text {hitung }}>\mathrm{r}_{\text {tabel }}$ & Valid \\
\hline
\end{tabular}

Sumber: Output SPSS

Dari tabel di atas diketahui bahwa nilai rhitung lebih besar dari nilai rtabel $(0,1697)$; berarti bahwa semua pernyataan untuk mengukur variabel kepuasan adalah valid.

Tabel 3. Uji Validitas Variabel Loyalitas Nasabah

\begin{tabular}{|c|c|c|c|}
\hline Pernyataan & $\mathbf{r}_{\text {hitung }}$ & $\mathbf{r}_{\text {tabel }}(\mathbf{d f :} \mathbf{1 2 8})=\mathbf{0 , 1 6 9 7}$ & Keterangan \\
\hline Pernyataan 1 & 0,706 & $\mathrm{r}_{\text {hitung }}>\mathrm{r}_{\text {tabel }}$ & Valid \\
\hline Pernyataan 2 & 0,754 & $\mathrm{r}_{\text {hitung }}>\mathrm{r}_{\text {tabel }}$ & Valid \\
\hline Pernyataan 3 & 0,719 & $\mathrm{r}_{\text {hitung }}>\mathrm{r}_{\text {tabel }}$ & Valid \\
\hline Pernyataan 4 & 0,734 & $\mathrm{r}_{\text {hitung }}>\mathrm{r}_{\text {tabel }}$ & Valid \\
\hline Pernyataan 5 & 0,724 & $\mathrm{r}_{\text {hitung }}>\mathrm{r}_{\text {tabel }}$ & Valid \\
\hline Pernyataan 6 & 0,669 & $\mathrm{r}_{\text {hitung }}>\mathrm{r}_{\text {tabel }}$ & Valid \\
\hline
\end{tabular}

Sumber: Output SPSS

Tabel di atas memperlihatkan nilai rhitung lebih besar dari nilai rtabel $(0,1697)$; berarti bahwa semua pernyataan untuk mengukur variabel loyalitas nasabah adalah valid.

Uji reliabilitas dilakukan untuk suatu instrumen cukup dapat dipercaya untuk digunakan sebagai alat pengumpul data. Hasil uji reliabilitas tersaji pada tabel sebagai berikut:

Tabel 4. Hasil Uji Reliabilitas

\begin{tabular}{|l|c|c|}
\hline \multicolumn{1}{|c|}{ Variabel } & Crocbach Alpha & Keterangan \\
\hline Kinerja Pelayanan & 0,734 & Reliabel \\
\hline Kepuasan & 0,710 & Reliabel \\
\hline Loyalitas nasabah & 0,812 & Reliabel \\
\hline
\end{tabular}

Dari tabel 4. diketahui bahwa semua variabel memiliki nilai Cronbach Alpha di atas 0,70, sehingga dapat disimpulkan instrument penelitian reliabel. Setelah data mengenai kinerja pelayanan, kepuasan nasabah, dan loyalitas nasabah terkumpul melalui kuesioner yang diisi 
responden, selanjutnya dilakukan pengujian hipotesis. Namun sebelum uji hipotesis, terlebih dulu dilakukan pengujian asumsi klasik.

\section{Uji Asumsi Klasik}

\section{Normalitas Data}

Uji normalitas data untuk menguji apakah dalam model regresi, variabel pengganggu atau residual memiliki distribusi normal (Ghozali, 2016: 154). Uji normalitas data menggunakan uji Kolmogorov-Smirnov, berikut hasilnya:

Tabel 5. Hasil Uji One Sample Kolmogorov Smirnov

One-Sample Kolmogorov-Smirnov Test

\begin{tabular}{|c|c|c|}
\hline & & Unstandardized Residual \\
\hline $\mathrm{N}$ & & 138 \\
\hline \multirow[t]{2}{*}{ Normal Parameters ${ }^{\mathrm{a}}$} & Mean & 0,0000000 \\
\hline & Std. Deviation & 2,87452656 \\
\hline \multirow[t]{3}{*}{ Most Extreme Differences } & Absolute & 0,069 \\
\hline & Positive & 0,044 \\
\hline & Negative & $-0,069$ \\
\hline Kolmogorov-Smirnov Z & & 0,807 \\
\hline Asymp. Sig. (2-tailed) & & 0,533 \\
\hline
\end{tabular}

a. Test distribution is Normal.

Pada tabel di atas diketahui bahwa nilai sig. sebesar 0,533>0,05. Ini berarti residual data penelitian berdistribusi normal.

\section{Multikolinearitas}

Selanjutnya adalah uji multikolinieritas. Uji multikolinieritas bertujuan untuk mengetahui apakah ditemukan adanya korelasi yang sangat kuat antar variabel bebas (independen). Berdasarkan hasil uji multikolinearitas diperoleh hasil sebagai berikut:

Tabel 6. Hasil Uji Multikolinearitas

\begin{tabular}{|l|c|c|}
\hline $\begin{array}{c}\text { Variabel Bebas } \\
\text { Penelitian }\end{array}$ & $\begin{array}{c}\text { Variance Influence } \\
\text { Factor }(\text { VIF })\end{array}$ & Tolerance \\
\hline Kinerja Pelayanan & 1,042 & 0,960 \\
\hline Kepuasan & 1,042 & 0,960 \\
\hline
\end{tabular}

Sumber: Hasil SPSS

Dari tabel di atas diketahui nilai VIF untuk kedua variabel (kinerja pelayanan, dan kepuasan nasabah) sebesar 1,042 sedangkan nilai tolerance untuk kedua variabel adalah 0,960. Nilai VIF lebih kecil dari 10 dan nilai tolerance di atas 0,01 berarti bahwa di antara variabel bebas tidak terjadi multikolinieritas.

\section{Heteroskedastisitas}

Selanjutnya dilakukan uji heteroskedastisitas untuk memastikan bahwa tidak terjadi varians yang berbeda di antara responden penelitian dalam memberikan jawaban atas kuesioner yang diberikan. Menurut Ghozali (2005) model regresi yang baik adalah yang homokedastisitas atau tidak mengandung heteroskedastisitas. Untuk mengetahui hasil uji heteroskedastisitas maka dapat dilihat hasil scatterplot sebagai berikut: 
Scatterplot

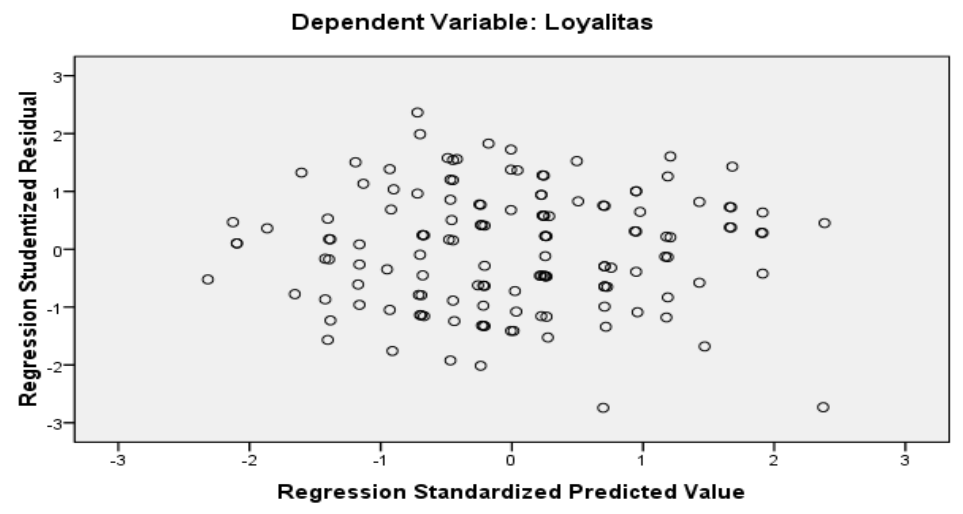

Gambar 1. Hasil Uji Heteroskedastisitas

Gambar tersebut menunjukkan titik-titik yang menyebar baik di atas maupun di bawah 0 (nol) atau dengan kata lain titik-titik tidak membentuk pola tertentu. Dari gambar tersebut dapat disimpulkan bahwa dalam model regresi tidak terjadi heteroskedastisitas.

Selain menggunakan Scatterplot, untuk mendeteksi heteroskedastisitas juga bisa dilakukan dengan uji korelasi Spearman (Priyatno, 2013). Kriteria penilaian adalah jika nilai signifikansi antara variabel independen dengan residual lebih dari 0,05 maka tidak terjadi heteroskedastistas. Hasil dari uji korelasi Spearman tersaji pada tabel sebagai berikut:

Tabel 7. Hasil Uji Spearman

Correlations

\begin{tabular}{|ll|r|r|r|}
\hline & & $\begin{array}{c}\text { Unstandardized } \\
\text { Residual }\end{array}$ & $\begin{array}{c}\text { Service } \\
\text { Performance }\end{array}$ & Kepuasan \\
\hline $\begin{array}{l}\text { Spearm } \\
\text { an's rho }\end{array}$ & Correlation Coefficient & 1,000 & 0,021 & 0,062 \\
& Sig. (2-tailed) &. & 0,07 & 0,471 \\
& $\mathrm{~N}$ & 138 & 138 & 138 \\
\cline { 2 - 5 } & Correlation Coefficient & 0,021 & 1,000 & $0,194^{*}$ \\
& Sig. (2-tailed) & 0,807 & 0,022 \\
& $\mathrm{~N}$ & 138 & 138 & 138 \\
\cline { 2 - 5 } & Correlation Coefficient & 0,062 & $0,194^{*}$ & 1,000 \\
& Sig. (2-tailed) & 0,471 & 0,022 & 138 \\
$\mathrm{~N}$ & 138 & 138 \\
\hline
\end{tabular}

*. Correlation is significant at the 0.05 level (2-tailed).

Tabel $7 \mathrm{di}$ atas memperlihatkan nilai signifikansi antara masing-masing variabel independen dengan residual lebih dari 0,05, yaitu sebesar 0,807 untuk korelasi antara service performance dengan residual. Korelasi antara kepuasan dengan residual sebesar 0,471. Oleh karena nilai signifikansi lebih besar dari 0,05 aka disimpulkan bahwa pada model regresi tidak terjadi heteroskedastistas. 


\section{Autokorelasi}

Berikutnya adalah uji autokorelasi. Uji autokorelasi adalah pengujian yang bertujuan untuk menguji apakah di dalam model regresi linier ada korelasi antara kesalahan pengganggu pada periode $t$ dengan kesalahan pengganggu pada periode $\mathrm{t}-1$ (Gozhali, 2005). Untuk mendeteksi adanya autokorelasi maka dilakukan Run test. Pengambilan keputusan untuk Run Test adalah jika nilai signifikansi lebih besar (>) dari 0,05 maka dalam model regresi tidak terjadi autokorelasi positif ataupun negatif.

Tabel 8. Hasil Run Test

\begin{tabular}{|l|r|}
\hline \multicolumn{2}{|c|}{ Runs Test } \\
\hline & Unstandardized Residual \\
\hline Test Value ${ }^{\mathrm{a}}$ & 0,02538 \\
Cases < Test Value & 69 \\
Cases >= Test Value & 69 \\
Total Cases & 138 \\
Number of Runs & 58 \\
Z & $-2,051$ \\
Asymp. Sig. (2-tailed) & 0,060 \\
\hline
\end{tabular}

Tabel 8 di atas memperlihatkan nilai signifikansi hasil Run Test sebesar 0,060>0,05. Hal ini berarti dapat disimpulkan dalam model regresi tidak terjadi autokorelasi. Setelah lulus uji asumsi klasik selanjutnya dilakukan pengujian hipotesis.

\section{Koefisien Determinasi}

Tabel 9. Koefisien Determinasi

\begin{tabular}{|c|c|c|c|}
\hline $\mathbf{R}$ & R Square & Adjusted R Square & $\begin{array}{c}\text { Standard error of the } \\
\text { estimate }\end{array}$ \\
\hline 0,363 & 0,132 & 0,119 & 2,896 \\
\hline
\end{tabular}

Sumber: Hasil Pengolahan Data

Tabel 9 memperlihatkan hasil Adjusted R Square sebesar 0,119. Ini berarti bahwa $11,9 \%$ variasi perubahan variabel loyalitas nasabah dapat dijelaskan oleh variabel kinerja pelayanan dan kepuasan nasabah. Sisanya sebesar 88,1 \% variabel loyalitas nasabah Bank Muamalat kantor cabang Madiun dipengaruhi oleh faktor lain di luar model penelitian.

Nilai t

Tabel 10. Hasil Analisis Regresi Berganda

Coefficients $^{\mathrm{a}}$

\begin{tabular}{|c|c|c|c|c|c|c|}
\hline \multirow{2}{*}{\multicolumn{2}{|c|}{ Model }} & \multicolumn{2}{|c|}{ Unstandardized Coefficients } & \multirow{2}{*}{$\begin{array}{c}\begin{array}{c}\text { Standardized } \\
\text { Coefficients }\end{array} \\
\text { Beta }\end{array}$} & \multirow[b]{2}{*}{$\mathrm{t}$} & \multirow[b]{2}{*}{ Sig. } \\
\hline & & $\mathrm{B}$ & Std. Error & & & \\
\hline \multirow[t]{3}{*}{1} & (Constant) & 11,406 & 2,811 & & 4,057 & 0,000 \\
\hline & Kinerja Pelayanan & 0,270 & 0,098 & 0,226 & 2,760 & 0,007 \\
\hline & Kepuasan & 0,259 & 0,087 & 0,242 & 2,956 & 0,004 \\
\hline
\end{tabular}

a. Dependent Variable: Loyalitas

Berdasarkan tabel 10, diketahui bahwa variabel kinerja pelayanan memiliki nilai thitung 2,760 dan nilai sig. 0,007. Kriteria uji t adalah hipotesis diterima atau Ho ditolak jika 
thitung lebih besar dari ttabel atau jika sig. $<\alpha$. Untuk memperoleh ttabel menggunakan uji dua sisi (dengan level of significant $(\alpha)=0,05(5 \%)$ dan degrees of freedom $=\mathrm{n}-\mathrm{k}=138-$ $3=135$ adalah sebesar $\pm 1,97769)$. Nilai thitung variabel kinerja pelayanan lebih besar dari nilai ttabel $(2,760>1,97769)$ dan nilai sig. $<0,05(0,007<0,05)$. Hal ini berarti bahwa kinerja pelayanan berpengaruh signifikan terhadap loyalitas nasabah.

Pelanggan yang terpuaskan nilai pribadinya dan mengalami perasaan yang positif terhadap pelayanan akan memiliki loyalitas yang tinggi terhadap perusahaan tersebut. Nasabah seringkali tidak loyal disebabkan oleh adanya pelayanan yang buruk atau kinerja pelayanan bank yang tidak sesuai harapan nasabah. Bila hasil evaluasi nasabah tentang layanan yang diperolehnya berkualitas, maka nasabah akan puas. Nasabah akan menyukai jasa/layanan yang menawarkan kualitas, kinerja dan pelengkap inovatif yang terbaik. Layanan yang berkualitas mampu memberikan hasil lebih dari yang diharapkan sehingga dapat memuaskan pelanggan. Kinerja layanan diukur dari aspek-aspek dimensi pelayanan meliputi penyediaan jasa fasilitas ruang yang nyaman, karyawan diupayakan cepat dan tanggap. Hasil penelitian ini mendukung penelitian Mulyana dan Sufiyanor (2009) bahwa kinerja pelayanan memiliki pengaruh secara langsung yang signifikan terhadap loyalitas pelanggan. Semakin tinggi kinerja pelayanan, konsumen akan semakin loyal.

Variabel kepuasan nasabah memiliki nilai thitung $=2,956$ dan nilai sig. $=0,004$. Nilai thitung $(2,956)>$ tabel $(1,97769)$ dan signifikansi $0,004<0,05$, maka hipotesis yang menyatakan bahwa "Kepuasan berpengaruh terhadap loyalitas nasabah", diterima. Manajemen bank dapat meningkatkan kinerja pelayanan yang diberikan kepada nasabah. Jika kinerja pelayanan yang disampaikan bank sesuai harapan nasabah, maka nasabah akan merasa puas. Terciptanya kepuasan nasabah bermanfaat untuk menciptakan loyalitas pelanggan.

Kinerja pelayanan yang baik akan menciptakan kepuasan bagi para nasabahnya. Setelah nasabah merasa puas dengan produk atau jasa yang diterimanya, nasabah akan membandingkan pelayanan yang diberikan. Apabila nasabah merasa puas, mereka akan membeli ulang serta merekomendasikannya kepada orang lain. Apabila nasabah memiliki persepsi yang positif atas kinerja layanan yang disampaikan pihak bank, nasabah akan merasa puas, sehingga nasabah tersebut berusaha untuk tetap memilih Bank Muamalat Indonesia, Tbk. Cabang Madiun dalam memenuhi kebutuhan layanan perbankannya dan akan memberi saran kepada orang lain untuk menjadi nasabah baru.

\section{Nilai F}

Tabel 11. Nilai F

ANOVA $^{\mathrm{b}}$

\begin{tabular}{|ll|r|r|r|c|c|}
\hline Model & & Sum of Squares & df & Mean Square & F & Sig. \\
\hline 1 & Regression & 171,519 & 2 & 85,759 & 10,227 & $0,000^{\mathrm{a}}$ \\
& Residual & 1132,018 & 135 & 8,385 & & \\
& Total & 1303,536 & 137 & & & \\
\hline
\end{tabular}

Dari nilai F dapat diketahui pengaruh variabel kinerja pelayanan dan kepuasan secara simultan terhadap variabel loyalitas nasabah. Tabel di atas menunjukkan bahwa nilai $\mathrm{F}$ sebesar 10,227 dan nilai signifikansi sebesar 0,000 sehingga dapat disimpulkan variabel 
kinerja pelayanan dan kepuasan berpengaruh secara simultan terhadap variabel loyalitas nasabah.

\section{SIMPULAN DAN SARAN}

Berdasarkan hasil analisis dan pembahasan, maka kesimpulan yang dapat diambil dari penelitian ini adalah kinerja pelayanan berpengaruh terhadap loyalitas nasabah Bank Muamalat, Tbk. Cabang Madiun. Kepuasan berpengaruh terhadap loyalitas nasabah Bank Muamalat, Tbk. Cabang Madiun. Kinerja pelayanan dan kepuasan secara simultan berpengaruh terhadap loyalitas nasabah Bank Muamalat, Tbk. Cabang Madiun. Kinerja pelayanan diukur dari perasaan nasabah pada saat menerima kualitas layanan. Jika layanan yang disampaikan pihak bank berkualitas, maka nasabah akan bersikap loyal terhadap bank. Loyalitas nasabah dapat dicapai apabila terdapat kepuasan atas layanan. Apabila kinerja pelayanan yang disampaikan pihak bank dapat memuaskan nasabah, maka akan tercapai loyalitas nasabah.

Dari simpulan hasil penelitian tersebut maka saran yang dapat diberikan bagi Bank Muamalat Indonesia, Tbk. Cabang Madiun dapat meningkatkan kinerja pelayanan. Hal itu bisa dilakukan dengan memperbaiki fasilitas dan sarana pendukung layanan yang ada di bank, karyawan bank yang profesional, pelayanan kepada pelanggan secara tepat waktu, serta responsif terhadap masalah yang dihadapi nasabah, sehingga diharapkan dapat meningkatkan loyalitas nasabah. Sedangkan untuk penelitian lebih lanjut dapat dikaji faktor lain yang mempengaruhi loyalitas nasabah, misalnya, suku bunga kredit dan tabungan, brand image.

\section{DAFTAR PUSTAKA}

Arikunto, Suharsimi. 2010. Prosedur Penelitian Suatu Pendekatan Praktek. Jakarta: Rineka Cipta.

Cronin, Joseph J. and Taylor, Steve A. 1994. SERVPERF Versus SERVQUAL: Reconciling Performance Based and Perception Minus Expectations Measurement of Service Quality. Journal of Marketing, 58: 125-131.

Ghozali, Imam. 2016. Aplikasi Analisis Multivariate dengan Program IBM SPSS 23. Semarang: Badan Penerbit Universitas Diponegoro.

Gomez, G. and Sanchez, R. 2005. End-to-End Quality of Service over Cellular Networks. New Jersey: John Wiley \& Sons Ltd.

Griffin, Jill. 2005. Customer Loyalty: Menumbuhkan dan Mempertahankan Kesetiaan Pelangan. Jakarta: Erlangga.

Harini, Cicik. 2015. Pengaruh Kualitas Layanan Terhadap Reputasi, Kepuasan dan Loyalitas Nasabah (Studi pada Nasabah Bank Mandiri Cabang Pemuda Semarang). Jurnal Ekonomi dan Bisnis Kontemporer. Vol. 1. No. 02. hal. 40-51. 
Mulyana dan Sufiyanor. 2009. Analisis Dampak Service Performance dan Kepuasan Terhadap Loyalitas Pelanggan. Jurnal Sultan Agung. Vol. XLV. No. 119. hal. 73-89.

Priyatno, D. 2013. Analisis Korelasi, Regresi, dan Multivariate dengan SPSS. Yogyakarta: Gava Media.

Sugiyono. 2010 Metode Penelitian Pendekatan Kuantitatif. Kualitatif. $R$ \& D. Bandung: Alfabeta.

Suryani. 2008. Perilaku Konsumen. Yogyakarta: Graha Ilmu.

Tjiptono, Fandy dan Chandra, Gregorius. 2012. Pemasaran Strategik. Edisi 2. Penerbit Andi. Yogyakarta. 
